\title{
Comparison of Quality of Bologna Sausage Manufactured by Electron Beam or X-Ray Irradiated Ground Pork
}

\author{
Mee-Hye Shin ${ }^{1}$, Ju-Woon Lee, Young-Min Yoon, Jong Heon Kim, Byeong-Geum Moon, \\ Jae-Hun Kim, and Beom-Suk Song* \\ Advanced Radiation Technology Institute, Korea Atomic Energy Research Institute, Jeongeup 580-185, Korea \\ ${ }^{I}$ Department of Food Technology and Services, Eulji University, Sungnam 461-713, Korea
}

\begin{abstract}
Ground lean pork was irradiated by an electron beam or X-rays to compare the effects of two types of radiation generated by a linear accelerator on the quality of Bologna sausage as a model meat product. Raw ground lean pork was vacuum packaged at a thickness of $1.5 \mathrm{~cm}$ and irradiated at doses of 2, 4, 6, 8, or $10 \mathrm{kGy}$ by an electron beam $(2.5 \mathrm{MeV})$ or X-rays $(5$ $\mathrm{MeV}$ ). Solubility of myofibrillar proteins, bacterial counts, and thiobarbituric acid reactive substance (TBARS) values were determined for raw meat samples. Bologna sausage was manufactured using the irradiated lean pork, and total bacterial counts, TBARS values, and quality properties (color differences, cooking yield, texture, and palatability) were determined. Irradiation increased the solubility of myofibrillar proteins in a dose-dependent manner $(p<0.05)$. Bacterial contamination of the raw meat was reduced as the absorbed dose increased, and the reduction was the same for both radiation types. Differences were observed only between irradiated and non-irradiated samples $(p<0.05)$. X-ray irradiation may serve as an alternative to gamma irradiation and electron beam irradiation.
\end{abstract}

Keywords: electron beam, x-ray, food irradiation, ground lean pork, bologna sausage

\section{Introduction}

Food may be irradiated with three different types of radiation: gamma rays emitted by a radioactive source (cobalt-60 or cesium-137), electrons accelerated to high energies, and X-rays produced from high-energy electrons striking a target material with a high atomic number (Gregoire et al., 2003). The technical advantages of highenergy X-rays are better power utilization, reduced treatment time, and improved dose uniformity. The practical results are higher production rates, lower treatment costs, and better product quality (Cleland and Stichelbaut, 2013). In published research, gamma rays from radioactive isotopes are the most widely used type of ionizing radiation. Nevertheless, there is a general feeling that in the next decade, the majority of industrial radioactive sources will be replaced by the new, powerful electron accelerators as public acceptance grows (Byun et al., 2009; Cleland and Stichelbaut, 2013). One of the advantages of electron ac-

\footnotetext{
*Corresponding author: Beom-Suk Song, Advanced Radiation Technology Institute, Korea Atomic Energy Research Institute, Jeongeup 580-185, Korea. Tel: +82-63-570-3211, Fax: +8263-570-3218, E-mail: sbs0110@kaeri.re.kr
}

celerators compared with gamma ray sources is that they can be switched from the electron beam mode to the Xray mode, thereby providing a wide range of dose rates (Miller, 2003). Several reports have indicated that X-ray and electron beam irradiation have similar effects on foods and agricultural commodities (Palou et al., 2007; Van Calenberg et al., 1998, 1999).

To avoid the possibility of measurable food activation via photonuclear reactions, the kinetic energy of an electron beam for direct irradiation is limited to $10 \mathrm{MeV}$ by regulation, while the kinetic energy limit for X-ray irradiation is $5 \mathrm{MeV}$. Scientific studies have shown that a limit of $7.5 \mathrm{MeV}$ is safe (FAO/IAEA, 1995), and the U.S. Food and Drug Administration has approved the use of 7.5 $\mathrm{MeV}$ accelerators (Food and Drug Administration, 2008). High-energy X-rays are suitable for irradiation of materials and products that are too thick to be penetrated by energetic electron beams. Some of the practical applications of high-energy X-rays are the same as those of gamma rays from cobalt-60 sources (Cleland and Stichelbaut, 2013). X-rays have much higher penetration power than high-energy electrons and are suitable for commercial treatment of pallet loads of produce in conveyor systems (McLaughlin, 1999). In some cases, when a product 
cannot be treated with an electron beam because of high density and thickness or with cobalt- 60 because of regulatory restrictions, X-rays may be the only solution. However, with the use of X-rays, the main problems are achieving high-throughput processing with an acceptable dose uniformity ratio in the irradiated object (Lazurik et al., 2007), and the high cost and low energy efficiency compared with gamma or electron beam irradiation (Sadat, 2004). It is expected that the use of X-rays for food irradiation will continue to expand, considering that the supply of accelerators is increasing internationally (Cleland and Stichelbaut, 2013). However, most studies that have compared the effects of different types of ionizing radiation on foods have compared gamma rays and electron beams (Choi et al., 2009; Kim et al., 2010a, 2010b; Park et al., 2010).

In this study, we compared the effects of electron beam and X-ray irradiation on food quality using Bologna sausage as a model meat product. Bologna sausage was manufactured with ground lean pork irradiated with an electron beam or X-rays generated by a linear accelerator, and the quality properties of the sausage were determined.

\section{Materials and Methods}

\section{Preparation of meat samples}

Vacuum-packaged and refrigerated lean pork (ham cut) and frozen pork backfat were obtained within $48 \mathrm{~h}$ of slaughter from a local meat packer. The lean meat and backfat were ground with a mincer (model 160, Fatosa, Spain) through a $9 \mathrm{~mm}$ plate and then through a $3 \mathrm{~mm}$ plate. Ground pork (500 g) was vacuum packaged (75 $\mathrm{cmHg}$ pulled) in sterilized oxygen-impermeable nylon bags $(2 \mathrm{~mL} \mathrm{O})_{2} / \mathrm{m}^{2}$ per $24 \mathrm{~h}$ at $0^{\circ} \mathrm{C} ; 20 \mathrm{~cm} \times 30 \mathrm{~cm}$; Sunkyung Co., Ltd., Korea) at a thickness of $1.5 \mathrm{~cm}$ to avoid confounding due to differences in penetration depth between radiation types. Although previous studies have indicated that the effects of irradiation do not differ among radiation types (Commission of the European Communities, 1986), it is necessary to be aware of differences in penetration depth. Electrons are far less penetrative than gamma rays and X-rays. The optimum thickness for double-sided irradiation of materials with unit density is approximately $8 \mathrm{~cm}$ for $10 \mathrm{MeV}$ electrons and $25 \mathrm{~cm}$ for 5 MeV X-rays and gamma rays (Woods and Pikaev, 1994). After samples had been packaged in a vacuum packaging machine (Leepack, Hanguk Electronic, Korea), they were irradiated with an electron beam or X-rays at the designated doses.

\section{Electron beam and $X$-ray irradiation}

Packaged lean meat samples were irradiated at doses of 0 (control), 2, 4, 6, 8, and $10 \mathrm{kGy}$. Electron beam irradiation and X-ray irradiation were performed with an ELV-4 electron accelerator $(2.5 \mathrm{MeV})$ and an X-ray linear accelerator $(15 \mathrm{~kW}, 5 \mathrm{MeV})$, respectively, at about $20^{\circ} \mathrm{C}$ at $\mathrm{EB}$ Tech Co. (Korea). Dose rates were $20 \mathrm{kGy} / \mathrm{h}$ for electron beam irradiation and $5 \mathrm{kGy} / \mathrm{h}$ for X-ray irradiation. Actual doses were determined by placing $2 \mathrm{~cm}^{2}$ radiochromic dosimetry films (Gafchromic HD-810, International Specialty Products, USA) at two different positions (top and bottom) with each sample. Readings (nine per dose) were made with a spectrophotometer at $560 \mathrm{~nm}$ (Van Calenberg et al., 1999). After irradiation, samples were stored at $4^{\circ} \mathrm{C}$ and used for subsequent experiments.

\section{Determination of solubility of myofibrillar protein}

To determine the effect of electron beam or X-ray irradiation on the solubility of myofibrillar protein of ground pork, we prepared protein solutions from irradiated ground lean pork using a previously described method (Wagner and Anon, 1986) with slight modifications. In brief, $2 \mathrm{~g}$ of lean pork was put into a tube and homogenized in 20 $\mathrm{mL}$ of cold phosphate-buffered saline (PBS; 0.15 $\mathrm{M} \mathrm{NaCl}$, $\mathrm{pH}$ 7.4) using a homogenizer (DIAX 900, Heidolph Co., Ltd., Germany) within an ice-water bath. The homogenate was centrifuged at $9,000 \mathrm{~g}$ for $20 \mathrm{~min}$ at $4^{\circ} \mathrm{C}$ and the supernatant was discarded. The precipitate was washed with $20 \mathrm{~mL}$ of PBS by vortexing for $3 \mathrm{~min}$ and centrifuged as described above. The washing process was performed twice. For preparation of salt-soluble myofibrillar protein solution, washed precipitate was put into a tube and homogenized in $20 \mathrm{~mL}$ of cold high-salt PBS (0.6 M $\mathrm{NaCl}, \mathrm{pH}$ 7.4) using the homogenizer within an ice-water bath. The homogenate was centrifuged at 10,000 $\mathrm{g}$ for 20 $\min$ at $4^{\circ} \mathrm{C}$ and the supernatant was filtered through Whatman No. 42 filter paper. The filtered supernatant was used as salt-soluble protein solution. The bicinchoninic acid (BCA) method (Hill and Straka, 1988) was used to determine the concentrations of the myofibrillar protein solutions using a BCA protein assay kit (Sigma Chemical Co., USA). Bovine serum albumin (Sigma Chemical Co.) solutions of 1.0 to $10.0 \mathrm{mg} / \mathrm{mL}$ were used as standards.

\section{Manufacture of Bologna sausage}

Bologna sausage was prepared using ground lean pork irradiated with an electron beam or X-rays at designated doses $(2,4,6,8$, or $10 \mathrm{kGy})$ to compare the effects of different forms of accelerator-generated radiation on the qua- 
lity of pork products. Bologna sausage was prepared as previously described (Byun et al., 2000; Jo et al., 2001). Sodium triphosphate, sodium nitrite, and spice mix (35\% black pepper powder, $25 \%$ coriander powder, $19 \%$ dextrose, $5 \%$ nutmeg powder, $5 \%$ caraway powder, $5 \%$ chili powder, $5 \%$ mustard powder, and $1 \%$ garlic powder) were purchased from Woosung Co., Ltd. (Korea), and salt and sugar were purchased from a local market. Lean pork (ham cut; $12 \mathrm{~kg}$ ), salt (300 g), sodium nitrite (4 g), sodium phosphate $(60 \mathrm{~g})$, and ice $(2 \mathrm{~kg})$ were placed in a bowl cutter (C-75, Fatosa) and mixed for about $1 \mathrm{~min}$ at high speed. When the temperature of the mixture had decreased by about $2^{\circ} \mathrm{C}$, ground pork backfat $(4 \mathrm{~kg})$ was added and the ingredients were mixed until the temperature reached $10^{\circ} \mathrm{C}$. The remaining $2 \mathrm{~kg}$ of ice, the spice mix (100 g), and sugar ( $40 \mathrm{~g})$ were added and mixed in until the temperature of the mixture reached $13^{\circ} \mathrm{C}$. The total emulsification time was about $10 \mathrm{~min}$ and the temperature of the processing room was $15^{\circ} \mathrm{C}$. The meat batters were stuffed (Patron Sausage Filler MWF 591, MADO, Netherlands) into 50-mm cellophane casings $(n=40)$ (Woosung Co., Ltd.). The Bologna sausages were weighed and then cooked in a cooker (Frocomat 1200, Franke GmbH $\&$ Co., Germany) to an internal temperature of $70^{\circ} \mathrm{C}$. The cooked sausages were water-spray cooled for $5 \mathrm{~min}$ and dried at room temperature for $30 \mathrm{~min}$. The sausages were weighed to determine the cooking yield, and the casings were removed from all except five sausages, which were used for sensory evaluation and determination of texture. Dressed Bologna sausages were cut into $1.5 \mathrm{~cm}$ thick slices, vacuum packaged, and stored at $5^{\circ} \mathrm{C}$ for subsequent experiments.

\section{Microbiological evaluation}

To determine total aerobic bacterial populations in raw lean pork and sausage samples, we obtained total aerobic plate counts by the method of Oh et al. (2000). Briefly, 10 -g portions of sausages were placed aseptically in a sterile nylon bag $(10 \times 15 \mathrm{~cm}$; Sunkyung Co., Ltd.) containing $90 \mathrm{~mL}$ of $0.1 \%$ sterile peptone water (Difco Laboratories, USA) and pommelled for 2 min using a Stomacher 400 lab blender (Seward Medical, UK). Aliquots of the pommelled samples were serially diluted with $0.1 \%$ sterile peptone water, and $0.1 \mathrm{~mL}$ portions of the dilutions were plated in triplicate on plate count agar (Difco Laboratories). The plates were then incubated at $37^{\circ} \mathrm{C}$ for $48 \mathrm{~h}$, and visible bacterial colonies on plates were determined as $\log$ colony-forming units (CFU) per gram.

\section{2-Thiobarbituric acid reactive substance (TBARS) values}

To assess lipid oxidation of raw lean pork and Bologna sausage, we measured TBARS levels using the method of Byun et al. (2000). A sample of raw lean pork or Bologna sausage $(5 \mathrm{~g})$ was homogenized in a $50-\mathrm{mL}$ centrifuge tube with $50 \mu \mathrm{L}$ of butylated hydroxyanisole (7.2\% in ethanol) and $15 \mathrm{~mL}$ of distilled water, using a homogenizer (DIAX 900). Then, 1-mL portions of the homogenates were mixed with $3 \mathrm{~mL}$ of $20 \mathrm{mM}$ 2-thiobarbituric acid ( $15 \%$ in trichloroacetic acid solution), heated in boiling water for $15 \mathrm{~min}$, and centrifuged for $10 \mathrm{~min}$ at $2,500 \mathrm{~g}$ (Union 5KR, Hanil Science Industrial Co., Ltd., Korea). The absorbance of the supernatant was measured at 532 $\mathrm{nm}$ with a spectrophotometer (UV1600 PC, Shimadzu, Japan). Values are reported as micrograms of malondialdehyde per gram.

\section{Quality evaluation of Bologna sausages}

\section{Textural properties}

All texture analyses were conducted at ambient temperature $\left(20^{\circ} \mathrm{C}\right)$ according to the method of Byun et al. (2002), using a texture analyzer system (TA.XT2i, Stable Micro Systems, England) equipped with a probe $(1.0 \mathrm{~cm}$ thick).

Hunter color values $\left(L^{*}, a^{*}\right.$, and $\left.b^{*}\right)$

Hunter color values - $\mathrm{L}^{*}$ (lightness), $a^{*}$ (redness), and $b^{*}$ (yellowness) - of the sausage surface were measured using a color difference meter (spectrophotometer model CM-3500d, Minolta Co., Japan). Standard values were as follows: $\mathrm{L}^{*}, 90.5 ; a^{*}, 0.4$; and $b^{*}, 11.0$.

\section{Sensory evaluation}

Sensory evaluation of the sausages was conducted using a 21-member panel trained as described by Byun et al. (2000). Panelists scored each sample using a 7-point descriptive scale, where $1=$ extremely dislike or extremely weak and $7=$ extremely like or extremely strong, for color, texture, and flavor. Bologna sausages were steeped in an $85^{\circ} \mathrm{C}$ water bath until an internal temperature of $65^{\circ} \mathrm{C}$ was reached (about $20 \mathrm{~min}$ ), cut into $1 \mathrm{~cm}$ thick slices, put on a white dish, and then served to panel members.

\section{Statistical analysis}

Data were analyzed by the general linear procedures, least squares means with limited standard deviations, and Duncan's multiple-range test of SAS software (SAS, 2008). 


\section{Results and Discussion}

\section{Protein solubility}

Table 1 shows the solubility of myofibrillar (salt-soluble) protein of ground lean pork irradiated with an electron beam or X-rays. Irradiation increased the solubility of myofibrillar proteins in a dose-dependent manner $(p<$ 0.05 ). The concentration of the myofibrillar protein solution was $3.11 \mathrm{mg} / \mathrm{mL}$ for the non-irradiated sample. For the samples irradiated at $2 \mathrm{kGy}$, the protein concentrations were $3.32 \mathrm{mg} / \mathrm{mL}$ following electron beam irradiation and $3.24 \mathrm{mg} / \mathrm{mL}$ following X-ray irradiation. At 10 $\mathrm{kGy}$, the concentration of myofibrillar proteins was 3.82 $\mathrm{mg} / \mathrm{mL}$ following electron beam irradiation and $3.76 \mathrm{mg} /$ $\mathrm{mL}$ following X-ray irradiation. In a previous study (Latreille et al., 1993), the solubility of myofibrillar proteins increased slightly in gamma-irradiated pork and beef, depending on the absorbed dose. Meat compounds are affected by treatment with ionizing radiation directly and indirectly (Fox et al., 1995; Taub et al., 1979). Meat properties such as protein solubility, water-holding capacity, and texture can be changed by radiolytic products generated by high-energy radiolysis of water (International Consultant Group of Food Irradiation, 1996). Changes induced by ionizing radiation may increase the solubility and emulsifying capacity of myofibrillar proteins in meat batter (Byun et al., 2000; Lacroix et al., 2000).

\section{Bacterial evaluation of raw lean pork and Bologna sausage}

Table 2 shows the survival of bacteria in raw lean pork irradiated with an electron beam or X-rays and Bologna sausage made with irradiated raw lean pork. The bacterial population in non-irradiated raw lean pork was $4.91 \mathrm{Log}$ $\mathrm{CFU} / \mathrm{g}$. Both electron beam and X-ray irradiation reduced the total bacterial counts of raw meat, and the reduction was dependent upon the dose. No bacterial growth was observed in samples irradiated with a dose over $8 \mathrm{kGy}$. At $2 \mathrm{kGy}, \mathrm{X}$-ray irradiation was more effective at reducing the initial bacterial contamination level than electron beam irradiation. However, the differences between radiation types were indistinguishable at doses of $4 \mathrm{kGy}$ and $6 \mathrm{kGy}$ $(p>0.05)$. The bacterial population was reduced to about $1.39 \mathrm{Log}$ CFU/g after manufacturing the sausage, and no bacterial growth was observed from the sausages made with lean pork irradiated with doses over $6 \mathrm{kGy}$. In their comparison of X-rays and electron beams, Van Calenberg et al. (1999) reported that the microbiological quality of minced chicken meat was the same regardless of radiation type. Our results show that electron beams and Xrays were equally effective for inactivating bacteria in the tested minced lean pork and may serve as an alternative to gamma irradiation. However, it is also important to consider the differences in penetration depth between the radiation types (Woods and Pikaev, 1994).

\section{TBARS levels of raw lean pork and Bologna sau- sage}

Table 3 shows the TBARS values for raw lean pork irradiated with an electron beam or X-rays and Bologna sausage made with irradiated pork. TBARS levels in raw lean pork were increased by irradiation $(p<0.05)$, which is

Table 1. Solubility of myofibrillar protein $(\mathrm{mg} / \mathrm{mL})$ from lean pork irradiated by an electron beam or X-rays

\begin{tabular}{cccccc}
\hline \hline \multirow{2}{*}{ Radiation source } & \multicolumn{5}{c}{ Irradiation dose (kGy) } \\
\cline { 2 - 6 } & $0^{1}$ & 2 & 4 & 6 & 8 \\
\hline Electron beam & \multirow{2}{*}{$3.11 \pm 0.13^{a}$} & $3.32 \pm 0.23^{b}$ & $3.52 \pm 0.16^{b c}$ & $3.60 \pm 0.15^{c}$ & $3.82 \pm 0.07^{d}$ \\
X-rays & & $3.24 \pm 0.16^{b}$ & $3.46 \pm 0.23^{b c}$ & $3.58 \pm 0.11^{c}$ & $3.76 \pm 0.12^{d}$ \\
\hline
\end{tabular}

Values are means \pm standard deviation $(\mathrm{n}=5)$. Means in the same row with different lowercase letters are significantly different $(p<0.05)$.

${ }^{1}$ Non-irradiated lean pork ( $\left.0 \mathrm{kGy}\right)$ was used as a control for both irradiation treatments.

Table 2. Survivability of bacteria (Log CFU/g) in raw lean pork irradiated by an electron beam or X-rays and Bologna sausage manufactured with irradiated meat

\begin{tabular}{cccccccc}
\hline \hline \multirow{2}{*}{ Samples } & \multirow{2}{*}{ Radiation source } & \multicolumn{5}{c}{ Irradiation dose (kGy) } \\
\cline { 3 - 7 } & & $0^{1}$ & 2 & 4 & 6 & 8 & 10 \\
\hline \multirow{2}{*}{ Raw lean pork } & Electron beam & \multirow{2}{*}{$4.91 \pm 0.02^{a}$} & $3.22 \pm 0.03^{b, X}$ & $2.40 \pm 0.16^{c}$ & $2.03 \pm 0.10^{d}$ & NG & NG \\
& X-rays & & $2.92 \pm 0.08^{b, Y}$ & $2.41 \pm 0.08^{c}$ & $1.97 \pm 0.14^{d}$ & NG & NG \\
\hline \multirow{2}{*}{ Bologna sausage } & Electron beam & \multirow{2}{*}{$3.52 \pm 0.05^{a}$} & $1.93 \pm 0.04^{b}$ & $1.03 \pm 0.04^{c}$ & NG & NG & NG \\
& X-rays & & $1.92 \pm 0.11^{b}$ & $1.02 \pm 0.11^{c}$ & NG & NG & NG \\
\hline
\end{tabular}

Values are means \pm standard deviation $(\mathrm{n}=5)$. Means in the same row with different lowercase letters are significantly different $(p<0.05)$. For raw lean pork samples, means in the same column with different uppercase letters are significantly different $(p<0.05)$. NG, no growth $(<1 \mathrm{Log}$ CFU/g).

${ }^{1}$ Non-irradiated lean pork and Bologna sausage manufactured from non-irradiated lean pork ( $\left.0 \mathrm{kGy}\right)$ were used as controls. 
Table 3. Thiobarbituric acid values ( $\mu \mathrm{g}$ malondialdehyde/g) in raw lean pork irradiated by an electron beam or X-rays and Bologna sausage manufactured with irradiated meat

\begin{tabular}{cccccccc}
\hline \hline \multirow{2}{*}{ Samples } & \multirow{2}{*}{ Radiation source } & \multicolumn{5}{c}{ Irradiation dose (kGy) } \\
\cline { 3 - 7 } & & $0^{1}$ & 2 & 4 & 6 & 8 & 10 \\
\hline \multirow{2}{*}{ Raw lean pork } & Electron beam & \multirow{2}{*}{$0.17 \pm 0.01^{a}$} & $0.20 \pm 0.01^{b}$ & $0.21 \pm 0.01^{b}$ & $0.22 \pm 0.01^{b}$ & $0.23 \pm 0.02^{b, c}$ & $0.24 \pm 0.02^{c}$ \\
& X-rays & & $0.22 \pm 0.02^{b}$ & $0.21 \pm 0.09^{b}$ & $0.23 \pm 0.01^{b}$ & $0.23 \pm 0.01^{b, c}$ & $0.24 \pm 0.01^{c}$ \\
\hline \multirow{2}{*}{ Bologna sausage } & Electron beam & \multirow{2}{*}{$0.22 \pm 0.01$} & $0.20 \pm 0.01$ & $0.21 \pm 0.01$ & $0.22 \pm 0.01$ & $0.23 \pm 0.02$ & $0.24 \pm 0.01$ \\
& X-rays & & $0.22 \pm 0.02$ & $0.24 \pm 0.01$ & $0.23 \pm 0.02$ & $0.24 \pm 0.01$ & $0.24 \pm 0.05$ \\
\hline
\end{tabular}

Values are means \pm standard deviation $(\mathrm{n}=5)$. For raw lean pork samples, means in the same row with different lowercase letters are significantly different $(p<0.05)$.

${ }^{1}$ Non-irradiated lean pork and Bologna sausage manufactured from non-irradiated lean pork ( $\left.0 \mathrm{kGy}\right)$ were used as controls.

consistent with the general observation that ionizing radiation increases lipid oxidation (Smith et al., 1960; Thayer, 1994). Lipid oxidation is generally higher in irradiated meat than in non-irradiated meat and is dependent upon the irradiation dose (Byun et al., 2000; Lee et al., 1999). However, there appears to be very little effect of irradiation on meat lipids at doses in the range of 0-10 kGy (Hampson et al., 1996). Our results indicate that irradiation of lean meat with a dose below $10 \mathrm{kGy}$ did not strongly induce lipid oxidation of the final meat product (Bologna sausage in this study).

\section{Quality properties of Bologna sausage}

\section{Color}

Electron beam or X-ray irradiation did not affect the color of Bologna sausage made from irradiated meat compared with sausage made from non-irradiated meat (Table 4). No significant differences in color were observed among samples $(p>0.05)$, regardless of radiation dose or type. Ionizing radiation can induce changes in meat color by promoting oxidation of myoglobin and denaturation of globins (Clarke and Richards, 1971). In a previous study (Byun et al., 2002), the redness of gammairradiated pork loin was increased by myoglobin oxidation induced by ionizing energy, and the increased redness was reduced during storage. The effects of radiation on the color of ground meat have not been well defined, and comparisons among radiation types have not been reported. Even though the color of ground meat can be improved by irradiation, it is difficult to maintain this improvement in processed meat products (Byun et al., 2000). However, the nitrites added to the manufactured Bologna sausage might help to maintain the redness of the final product.

\section{Cooking yield}

Radiation type and dose did not significantly affect the cooking yield of Bologna sausage manufactured from irradiated lean pork (Table 4). Cooking yield ranged from 95.14\% ( $2 \mathrm{kGy}$, electron beam irradiation) to $96.82 \%$ (8 kGy, X-ray irradiation) and was $96.75 \%$ for the control. Denaturation of meat proteins can induce changes in the processing properties of meat, and emulsifying capability can also be changed by ionizing radiation. In a previous study (Lacroix et al., 2000), pork loins irradiated at a dose of $20 \mathrm{kGy}$ had a higher emulsifying capacity. The higher emulsifying capacity of irradiated samples indicated a slight radiolysis-related increase in the emulsifying capacity of pork proteins. It was expected that the higher emulsifying capability would result in a higher cooking yield, but no effects of ionizing radiation on cooking yield were observed in this study.

Texture

Radiation type (electron beam or X-ray) and dose had no significant effect on the textural properties of Bologna sausage manufactured from irradiated pork, including hardness, elasticity, cohesiveness, break force, and fracturability (Table 4). Byun et al. (2000) also reported no differences in the textural properties of Bologna sausage made from gamma-irradiated beef compared with sausages made from non-irradiated meat.

\section{Palatability}

The palatability of Bologna sausage was organoleptically evaluated (for color, texture, and flavor) by the panels (Table 4). Color and texture were indistinguishable among all samples, but there were differences in flavor. In a previous study, no differences were observed between beef patties treated by gamma irradiation and those treated by electron beam irradiation (Park et al., 2010). However, in the current study, the flavor scores decreased as the irradiation dose increased, and there were significant differences between samples treated with electron beam or X-ray irradiation at 8 or $10 \mathrm{kGy}$ and the non-irra- 
Table 4. Color differences, cooking yield, texture, and palatability of Bologna sausages manufactured with lean pork irradiated by an electron beam or $\mathrm{X}$-rays

\begin{tabular}{|c|c|c|c|c|c|c|c|c|}
\hline & & \multirow{2}{*}{$\begin{array}{c}\text { Radiation } \\
\text { source }\end{array}$} & \multicolumn{6}{|c|}{ Irradiation dose (kGy) } \\
\hline & & & $0^{1}$ & 2 & 4 & 6 & 8 & 10 \\
\hline \multirow{6}{*}{$\begin{array}{c}\text { Color } \\
\text { differences }\end{array}$} & \multirow{2}{*}{$\begin{array}{l}\text { Lightness } \\
\text { (L) }\end{array}$} & \multirow{2}{*}{$\begin{array}{c}\text { Electron beam } \\
\text { X-rays }\end{array}$} & \multirow{2}{*}{$72.91 \pm 0.87$} & $72.51 \pm 1.17$ & $69.71 \pm 1.72$ & $71.73 \pm 1.94$ & $70.22 \pm 1.56$ & $70.32 \pm 1.35$ \\
\hline & & & & $72.42 \pm 1.24$ & $73.25 \pm 0.85$ & $72.51 \pm 0.48$ & $71.18 \pm 0.66$ & $72.67 \pm 1.34$ \\
\hline & \multirow{2}{*}{$\begin{array}{l}\text { Redness } \\
\text { (a) }\end{array}$} & \multirow{2}{*}{$\begin{array}{c}\text { Electron beam } \\
\text { X-rays }\end{array}$} & \multirow{2}{*}{$6.32 \pm 0.32$} & $6.53 \pm 0.63$ & $6.68 \pm 0.76$ & $6.27 \pm 0.86$ & $5.76 \pm 0.66$ & $6.45 \pm 0.56$ \\
\hline & & & & $6.29 \pm 0.75$ & $6.57 \pm 0.05$ & $6.55 \pm 0.36$ & $6.38 \pm 0.07$ & $6.84 \pm 0.90$ \\
\hline & \multirow{2}{*}{$\begin{array}{l}\text { Yellowness } \\
\qquad(b)\end{array}$} & \multirow{2}{*}{$\begin{array}{c}\text { Electron beam } \\
\text { X-rays }\end{array}$} & \multirow{2}{*}{$11.10 \pm 0.75$} & $11.12 \pm 0.75$ & $10.81 \pm 0.87$ & $11.15 \pm 1.06$ & $11.21 \pm 1.30$ & $10.93 \pm 1.15$ \\
\hline & & & & $11.13 \pm 0.19$ & $11.23 \pm 0.56$ & $12.01 \pm 0.17$ & $11.13 \pm 0.55$ & $11.03 \pm 0.57$ \\
\hline \multirow{2}{*}{\multicolumn{2}{|c|}{ Cooking yield ${ }^{2}(\%)$}} & Electron beam & \multirow{2}{*}{$96.75 \pm 0.61$} & $95.14 \pm 0.32$ & $95.96 \pm 0.73$ & $96.43 \pm 0.69$ & $96.78 \pm 0.71$ & $95.91 \pm 0.87$ \\
\hline & & $\mathrm{X}$-rays & & $96.17 \pm 1.08$ & $95.81 \pm 1.85$ & $96.01 \pm 0.91$ & $96.82 \pm 0.43$ & $96.14 \pm 0.48$ \\
\hline \multirow{10}{*}{ Texture } & \multirow{2}{*}{$\begin{array}{l}\text { Hardness } \\
\text { (kgf) }\end{array}$} & Electron beam & \multirow{2}{*}{$17.25 \pm 0.32$} & $18.17 \pm 0.17$ & $17.65 \pm 0.21$ & $17.16 \pm 0.52$ & $18.09 \pm 0.64$ & $17.87 \pm 0.21$ \\
\hline & & $\mathrm{X}$-rays & & $17.85 \pm 0.31$ & $17.55 \pm 0.11$ & $17.57 \pm 0.35$ & $17.47 \pm 0.25$ & $17.95 \pm 0.16$ \\
\hline & \multirow{2}{*}{$\begin{array}{l}\text { Fracturability } \\
\qquad(\mathrm{cm})\end{array}$} & Electron beam & \multirow{2}{*}{$8.10 \pm 0.54$} & $7.96 \pm 0.25$ & $7.54 \pm 0.21$ & $7.36 \pm 0.33$ & $7.87 \pm 0.24$ & $7.86 \pm 0.31$ \\
\hline & & $\mathrm{X}$-rays & & $8.02 \pm 0.17$ & $7.81 \pm 0.23$ & $7.82 \pm 0.42$ & $8.01 \pm 0.21$ & $7.92 \pm 0.22$ \\
\hline & \multirow{2}{*}{$\begin{array}{l}\text { Elasticity } \\
\text { (ratio) }\end{array}$} & Electron beam & \multirow{2}{*}{$8.56 \pm 0.25$} & $8.47 \pm 0.18$ & $8.67 \pm 0.26$ & $8.51 \pm 0.12$ & $8.69 \pm 0.21$ & $8.57 \pm 0.15$ \\
\hline & & $\mathrm{X}$-rays & & $8.61 \pm 0.31$ & $8.92 \pm 0.11$ & $8.71 \pm 0.32$ & $8.81 \pm 0.35$ & $8.69 \pm 0.24$ \\
\hline & \multirow{2}{*}{$\begin{array}{c}\text { Cohesiveness } \\
\text { (kgf) }\end{array}$} & Electron beam & \multirow{2}{*}{$6.21 \pm 0.36$} & $6.14 \pm 0.26$ & $6.24 \pm 0.11$ & $6.17 \pm 0.14$ & $6.25 \pm 0.16$ & $6.18 \pm 0.21$ \\
\hline & & $\mathrm{X}$-rays & & $6.25 \pm 0.14$ & $6.29 \pm 0.16$ & $6.21 \pm 0.18$ & $6.31 \pm 0.11$ & $6.29 \pm 0.15$ \\
\hline & \multirow{2}{*}{$\begin{array}{c}\text { Break force } \\
\text { (kgf) }\end{array}$} & Electron beam & \multirow{2}{*}{$5.18 \pm 0.21$} & $5.06 \pm 0.21$ & $5.16 \pm 0.17$ & $5.24 \pm 0.41$ & $5.18 \pm 0.20$ & $5.22 \pm 0.17$ \\
\hline & & $\mathrm{X}$-rays & & $5.24 \pm 0.18$ & $5.29 \pm 0.16$ & $5.31 \pm 0.14$ & $5.23 \pm 0.14$ & $5.20 \pm 0.11$ \\
\hline \multirow{6}{*}{ Palatability $^{3}$} & \multirow{2}{*}{ Color } & Electron beam & \multirow{2}{*}{$6.58 \pm 0.42$} & $6.54 \pm 0.36$ & $6.48 \pm 0.22$ & $6.56 \pm 0.24$ & $6.62 \pm 0.24$ & $6.49 \pm 0.25$ \\
\hline & & $\mathrm{X}$-rays & & $6.57 \pm 0.17$ & $6.69 \pm 0.25$ & $6.41 \pm 0.28$ & $6.39 \pm 0.12$ & $6.53 \pm 0.26$ \\
\hline & \multirow{2}{*}{ Texture } & Electron beam & \multirow{2}{*}{$6.69 \pm 0.27$} & $6.45 \pm 0.26$ & $6.57 \pm 0.22$ & $6.36 \pm 0.14$ & $6.54 \pm 0.25$ & $6.57 \pm 0.12$ \\
\hline & & $\mathrm{X}$-rays & & $6.51 \pm 0.24$ & $6.54 \pm 0.13$ & $6.45 \pm 0.21$ & $6.57 \pm 0.31$ & $6.58 \pm 0.22$ \\
\hline & \multirow{2}{*}{ Flavor } & Electron beam & \multirow{2}{*}{$6.43 \pm 0.38$} & $6.41 \pm 0.21$ & $6.37 \pm 0.28$ & $6.31 \pm 0.41$ & $6.24 \pm 0.11^{a}$ & $5.67 \pm 0.52^{b}$ \\
\hline & & $\mathrm{X}$-rays & & $6.48 \pm 0.22$ & $6.51 \pm 0.25$ & $6.32 \pm 0.32$ & $6.16 \pm 0.25^{a}$ & $5.58 \pm 0.38^{b}$ \\
\hline
\end{tabular}

Values are means \pm standard deviation $(\mathrm{n}=5)$. Means in the same row with different lowercase letters are significantly different $(p<0.05)$. kgf, kilogram-force.

${ }^{1}$ Bologna sausage manufactured from non-irradiated lean pork ( $\left.0 \mathrm{kGy}\right)$ was used as a control for both irradiation treatments.

${ }^{2}$ Cooking yield is the weight of Bologna sausage after cooking and cooling as a percentage of the weight of uncooked sausage.

${ }^{3}$ Palatability was assessed by a panel on a scale of 1 (very poor) to 7 (very good).

diated sample $(p>0.05)$. The panel detected an off-flavor ("wet dog" flavor) in samples treated with ionizing radiation at doses above $6 \mathrm{kGy}$. Sulfur-containing proteins can be denatured and/or broken down by the attack of radiolytic radicals with strong oxidation power (Dogbevi et al., 1999; Oh et al., 2004), and unexpected volatiles can be generated by the deamination of irradiated meat (Latreille et al., 1993).

\section{Conclusions}

Electron beam and X-ray irradiation had equivalent effects on the inactivation of bacteria and on lipid oxidation in the tested ground lean pork. Based on these results, Bologna sausage can be manufactured from irradiated meat, as its processing properties were unaffected by electron beam or X-ray irradiation at absorbed doses below $10 \mathrm{kGy}$. High-energy X-ray irradiation may serve as an alternative to gamma or electron beam irradiation.

\section{Acknowledgements}

This study was supported by the Nuclear Research \& Development Program of the National Research Foundation (2013M2A2A6043298).

\section{References}

1. Byun, M. W., Lee, J. W., Yook, H. S., Lee, K. H., Kim, S., Kim, W. J., and Kim, K. S. (2000) Effect of gamma irradiation on the raw meat in Bologna sausage production. Int. J. Food Sci. Technol. 35, 599-601.

2. Byun, M. W., Lee, J. W., Yook, H. S., Lee, K. H., and Kim, H. Y. (2002) Improvement of shelf stability and processing properties of meat products by gamma irradiation. Radiat. Phys. Chem. 63, 361-364.

3. Byun, M. W., Oh, S. H., Kim, J. H., Yoon, Y. H., Park, S. K., Kim, H. S., Kim, S. B., Hand, S. B., and Lee, J. W. (2009) Information channel effects on women intention to purchase irradiated food in Korea. Radiat. Phys. Chem. 78, 675-677. 
4. Choi, J. I., Kim, J. K., Srinivasan, P., Kim, J. H., Park, H. J., Byun, M. W., and Lee, J. W. (2009) Comparison of gamma ray and electron beam irradiation on extraction yield, morphological and antioxidant properties of polysaccharides from tamarind seed. Radiat. Phys. Chem. 78, 605-609.

5. Clarke, R. and Richards, J. F. (1971) Effect of $\gamma$-irradiation on beef myoglobin. J. Agr. Food Chem. 19, 170-174.

6. Cleland, M. R. and Stichelbaut, F. (2013) Radiation processing with high-energy X-rays. Radiat. Phys. Chem. 84, 91-99.

7. Commission of the European Communities (1986) Food Science Techniques. Reports of the Scientific Committee for Food. EUR 10480 EN, Commission for the European Communities, Brussels, Luxembourg.

8. Dogbevi, M. K., Vachon, C., and Lacroix, M. (1999) Physicochemical and microbiological changes in irradiated fresh pork loins. Meat Sci. 51, 349-354.

9. FAO/IAEA (1995) FAO/IAEA consultant meeting on the development of X-ray machines for food irradiation. Vienna, Austria.

10. Food and Drug Administration (2008) Department of Health and Human Services, Irradiation in the production, processing and handling of food, 21CFR Part 179 49593-603.

11. Fox, J. J. Jr., Lakritz, L., Hampson, J., Richardson, R., Ward, K., and Thayer, D. W. (1995) Gamma irradiation effects on thiamin and riboflavin in beef, lamb, pork, and turkey. $J$. Food Sci. 60, 593-603.

12. Gregoire, O., Cleland, M. R., Mittendorfer, J., Dababneh, S., Ehlermann, D. A. E., Fan, X., Kappeler, F., Logar, J., Meissner, J., Mullier, B., Stichelbaut, F., and Thayer, D. W. (2003) Radiological safety of food irradiation with high energy Xrays: theoretical expectations and experimental evidence. $R a$ diat. Phys. Chem. 67, 169-183.

13. Hampson, J. W., Fox, J. B., Lakritz, L., and Thayer, D. W. (1996) Effect of low dose gamma irradiation on lipids in five different meats. Meat Sci. 42, 271-276.

14. Hill, H. D. and Straka, J. G. (1988) Protein determination using bicinchoninic acid in the presence of sulfhydryl reagents. Anal. Biochem. 170, 203-208.

15. International Consultant Group of Food Irradiation (1996) Irradiation of red meat. IAEA-TECDOC-902, IAEA, Vienna, pp. 19-20.

16. Jo, C., Lee, J. W., Lee, K. H., Lee, H. J., and Byun, M. W. (2001) Effect of irradiation on $\mathrm{pH}$, color, and sensory quality of cooked pork sausage with added chitosan oligomer. $J$. Food Sci. Nutr. 6, 147-151.

17. Kim, H. J., Ham, J. S., Lee, J. W., Kim, K., Ha, S. D., and Jo, C. (2010a) Effects of gamma and electron beam irradiation on the survival of pathogens inoculated into sliced and pizza cheeses. Radiat. Phys. Chem. 79, 731-734.

18. Kim, B. H., Kim, H. J., Yoon, Y., Shin, M. G., and Lee, J. W. (2010b) Comparison of the effects of gamma ray and electron beam irradiation to improve safety of spices for meat processing. Korean J. Food Sci. An. 30, 124-132.

19. Lacroix, M., Smoragiewicz, W., Jobin, M., Latreille, B., and
Krzystyniak, K. (2000) Protein quality and microbiological changes in aerobically- or vacuum-packaged, irradiated fresh loins. Meat Sci. 56, 31-39.

20. Latreille, B., Lacroix, M., Icart, L., Simard, C., and Gagnon, M. (1993) Effect of dose and dose-rate of irradiation on emulsifying capacity of chicken proteins. Sci. Aliment. 13, 97-107.

21. Lazurik, V. T., Pismenesky, S. A., Popov, D. V., Rudychev, D. V., and Rudychev, V. G. (2007) An increase of utilization efficiency of X-ray beam. Radiat. Phys. Chem. 76, 1787-1791.

22. Lee, K. H., Yook, H. S., Lee, J. W., and Byun, M. W. (1999) Quenching mechanism and kinetics of ascorbyl palmitate for the reduction of the gamma irradiation-induced oxidation of oils. J. Am. Oil Chem. Soc. 76, 921-925.

23. McLaughlin, W. L. (1999) Gamma-ray sources vs. X-ray or electron beams for quarantine treatment. In: Proceedings of the Workshop on the Use of Irradiation as Quarantine Treatment of Food and Agricultural Commodities. Moy, J. H. and Wong, L. (eds) Hi, pp. 78-89.

24. Miller, R. B. (2003) Food irradiation using bremsstrahlung X-rays. Radiat. Phys. Chem. 68, 963-974.

25. Oh, S. H., Kim, J. H., Lee, J. W., Lee, Y. S., Park, K. S., Kim, J. G., Yook, H. S., and Byun, M. W. (2004). Effects of combined treatment of gamma irradiation and addition of rosemary extract powder on ready-to-eat hamburger steaks: I. Microbiological quality and shelf life. J. Korean Soc. Food Sci. Nutr. 33, 687-693.

26. Palou, L., Marcilla, A., Rojas-Argudo, C., Alonso, M., Jacas, J. A., and del Rio, M. A. (2007) Effects of X-ray irradiation and sodium carbonate treatments on postharvest Penicillium decay and quality attributes of clementine mandarins. Postharvest Biol. Tec. 46, 252-261.

27. Park, J. G., Yoon, Y., Park, J. N., Han, I. J., Song, B. S., Kim, J. H., Kim, W. G., Hwang, H. J., Han, S. B., and Lee, J. W. (2010) Effects of gamma irradiation and electron beam irradiation on quality, sensory, and bacterial populations in beef sausage patties. Meat Sci. 85, 368-372.

28. Sadat, T. (2004) Do we need X-rays? Radiat. Phys. Chem. 71, 543-547.

29. SAS (2008) SAS/STAT Software for PC. Release 9.2, SAS Institute Inc., Cary, NC, USA.

30. Smith, N. L., Tinsley, I. J., and Bubl, C. E. (1960) The thiobarbituric acid test in irradiation sterilized beef. Food Technol. 14, 317-320.

31. Taub, I. A., Robbins, F. M., Simic, M. G., Walker, J. E., and Wierbick, E. (1979) Effect of irradiation on meat proteins. Food Technol. 33, 184-193.

32. Thayer, D. W. (1994) Wholesomeness of irradiated foods. Food Technol. 48, 58-67.

33. Van Calenberg, S., Vanhaelewyn, G., Van Creemput, O., Callens, F., Mondelaers, W., and Huyghebaert, A. (1998) Comparison of the effect of X-ray and electron beam irradiation on some selected spices. LWT-Food Sci. Technol. 31, 252258.

34. Van Calenberg, S., Van Cleempu, O., Mondelaers, W., and 
Huyghebaert, A. (1999) Comparison of the effect of X-ray and electron beam irradiation on the microbiological quality of foodstuffs. LWT-Food Sci. Technol. 32, 372-376.

35. Wagner, J. R. and Anon, M. C. (1986) Effect of frozen storage on protein denaturation in bovine muscle. II. Myofibrillar ATPase activity and differential scanning calorimetric studies. J. Food Technol. 21, 9-18.

36. Woods, R. J. and Pikaev, A. K. (1994) Applied radiation chemistry: radiation processing. John Wiley \& Sons, Inc., NY, pp. 535-537.

$\overline{\text { (Received 2014.4.1/Revised 2014.6.12/Accepted 2014.6.26) }}$ 